\title{
NOTES
}

\section{AN UNPUBLISHED WHITMAN MANUSCRIPT ABOUT WRITING THE "HISTORY OF THE SECESSION WAR"}

Tipped into a copy of the first edition of Whitman's Drum-Taps (1865) housed in the Special Collections Department of the University of Rhode Island Library is an unpublished manuscript in Whitman's hand. In this manuscript, Whitman notes the plethora of books and articles appearing in the 1870s that set out to offer a history of the recent Civil War; Whitman's own Memoranda During the War (1875) was part of this explosion of published war memories a decade after the fighting stopped. In the brief manuscript (reproduced below), Whitman cautions that any full history of the war will have to wait for "the future to write":

There seems to be quite a prevalent disposition, partly from both from observers $\&$ actors, North and South, to eontribute contribute betimes to that History of the Secession War, which must yet go on $\left[\wedge\right.$ wait] some years to $\left[{ }^{\wedge} \mathrm{in}\right]$ the $\left[{ }^{\wedge}\right.$ for the full] gathering of its materials and wait for the future to write.

By the time he absorbed Memoranda into Specimen Days, Whitman would declare that "The Real War Will Never Get in the Books" (earlier, in a New York Weekly Graphic article, he had said "The Inner Points of the War Can Never Be Written"). ${ }^{1}$ This manuscript, however, seems more consonant with Whitman's meditations at the very end of Memoranda, where, in the final sentence of his fi-

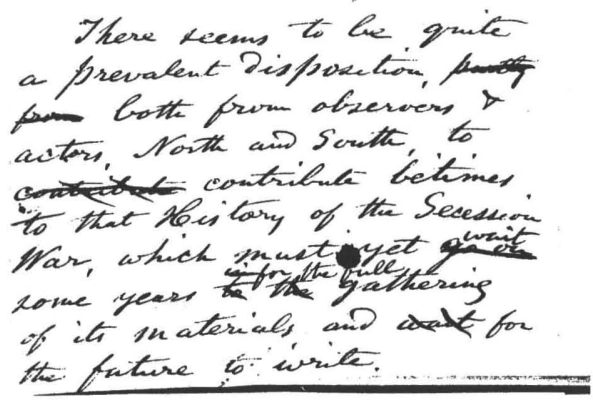
nal note, he concludes that "the real History of the United States-starting from that great convulsive struggle for Unity, triumphantly concluded, and the South victorious, after all-is only to be written at the remove of hundreds, perhaps a thousand, years hence."2

The University of Iowa

ED FOLSOM

\section{NOTES}

1 Floyd Stovall, ed., Prose Works 1892 (New York: New York University Press, 19631964), 1:115. 
2 Whitman, Memoranda During the War (Camden, NJ: Author's Publication, 18751876), 68. I am grateful to Sarina Wyatt, Assistant Archivist and Special Collections Librarian, University of Rhode Island, for drawing this manuscript to my attention, and to Christine S. Fagan, librarian at Roger Williams University, for curating (with Wyatt) a Whitman exhibition at Roger Williams in 2005 that displayed the manuscript.

\section{WHITMAN AND KATE FIELD}

To the long list of pioneering American feminists who admired Whitman another name may now be added: Kate Field (1838-1896), a journalist, travel writer, lecturer, actor, and model for the character of Henrietta Stackpole in Henry James's The Portrait of a Lady. ${ }^{1}$ In March 1866, as the New York correspondent of the Springfield Republican, Field alluded in passing to Whitman's "barbaric yawp," and eighteen months later, as the Saratoga correspondent of the Chicago Tribune, she referred to him as "a Cosmos-one of the roughs." She worked the latter reference to the poem "Walt Whitman" (later entitled "Song of Myself") into her lecture "Among the Adirondacks" (also called "Life in the Adirondacks" and "Out in the Woods") which she delivered dozens of times during the winter of 1869-1870-including dates in Boston, New York, Providence, Pittsburgh, Cleveland, Buffalo, Brooklyn, Newark, Chicago, Detroit, Milwaukee, and St. Paul-and occasionally during the 18701871 season (e.g., in Washington, D.C.). ${ }^{4}$ When she published the lecture under the title "In and Out of the Woods" in the Atlantic Almanac 1870, she added yet another quote from the poem: "I want to lounge in an attitude half lying and half sitting, and 'invite my soul."'"

Although there is no record indicating that Field and Whitman were acquainted, Field continued to praise the poet over the years. As the London correspondent of the Louisville fournal-Courier in the spring of 1876, she reported on the efforts of Robert Buchanan, William Rossetti, and others to raise a subscription in England for him. Whitman had described his financial plight in the West fersey Press in January, ${ }^{6}$ and excerpts from the article appeared in the London Athenoum for March $11,{ }^{7}$ the same day an anonymous New York correspondent for the London Daily News favorably reviewed Two Rivulets in its pages. ${ }^{8}$ Two days later, Robert Buchanan published a card in the Daily News to rally help for Whitman, ${ }^{9}$ and the following day a letter from William Rossetti appeared in the paper echoing Buchanan's suggestion. ${ }^{10}$ Over the next few days Buchanan qualified his criticism of Americans for failing to aid the poet, ${ }^{11}$ and Alfred Austin, the future English poet laureate, also wrote the Daily News to promote the subscription for Whitman. ${ }^{12}$ Field mentioned all of these developments - and even quoted about five hundred words from Buchanan's original appeal-in her April 18, 1876 London letter to the Louisville paper, as follows: ${ }^{13}$

I think that Walt Whitman has engrossed more public attention than anything or anybody after the brand-new empress of India. Thanks to an article reprinted in the Athenaeum from the West fersey Press, and thanks to the New York correspondent of the Daily News, the position of Walt Whitman is like to be thoroughly understood on both 